\title{
Structural Funds and European regional growth: comparison of effects among different programming periods.
}

\begin{abstract}
Strengthening social, economic and territorial cohesion is a central objective of the European Union (EU) and the Structural Funds reflect the main financial effort of the EU to pursue this goal. So far we have gone through four programming periods; to what extent the EU Funds have become more effective in promoting growth and reducing the disparities between EU Member countries is a matter of concern. We investigate the existence (or not) of learning effects and efficiency improvements following the reforms on Regional Policy. The study is applied to data from EU regions (EU-12), in the most recent programming periods where data are available. The results suggest an improvement of the Funds efficiency over growth in 2000-2006 when compared to the previous programming period. Moreover, the returns from investments of Funds tend to be higher in richer, higher-educated and more innovative regions. Finally, the Cohesion group has not been able to transform the large transfers received into additional growth.
\end{abstract}

Keywords: Regional economic growth, Structural Funds, Learning effects, Panel data JEL Codes: C23, O40, R11 


\section{Introduction}

Strengthening economic, social and territorial cohesion by reducing disparities between regions is a central objective of the $\mathrm{EU}$, together with the promotion of regional competitiveness. Indeed, the central goal of the EU Regional Policy is to reduce regional asymmetries and to promote economic and social cohesion among territories (Bachtler and Mendez 2007).

The regional policy finds its origins in the Treaty of Rome. However, the first mention to a formal Regional Policy occurred in the Single European Act (1986). Since then four programming periods have been completed (1989-1993, 1994-1999, 2000-2006 and 2007-2013).

The EU Regional Policy has evolved over time in scope, breadth and depth, although the guiding line has maintained itself all along, that is, the reduction of regional asymmetries and the promotion of economic and social cohesion among territories. A thorough reform regarding the allocation of Funds was carried out in 1988, following the enlargement of the Community to three relatively poor countries: Greece (1981), Portugal and Spain (1986). Also, the idea of the creation of a Single Market was an important guiding line for the reform. Structural Funds were thus integrated into an overarching Cohesion Policy, with the budget allocated to these transfers reaching a significant amount (ECU 64 billion). The focus turned to the poorest and most backward regions, in order to reduce the income gap and to promote cohesion among regions. The Funds would be attributed under a multi-annual program to strategic investments, requiring the involvement not only of supra-national and national agents, but also of regional and local partners.

In 1993 the Maastricht Treaty introduced the Cohesion Fund and the Committee of the Regions, being also introduced the principle of subsidiarity. In the period 1994-1999 the resources for the Structural and Cohesion Funds were doubled, reaching a third of the EU budget (ECU 168 billion). In 2000 the 'Lisbon Strategy' shifted the EU's priorities towards growth, jobs and innovation, and the priorities of Cohesion Policy were aligned to reflect this. The Cohesion Fund was created also to help poorer Members to deal with the creation of the Economic and Monetary Union (EMU). The number of Objectives was reduced to concentrate efforts on more specific areas, and the emphasis 
was on the monitoring of the efficiency of Funds for growth promotion and reduction of disparities among regions. In 2004 ten new countries joined the EU. The Budget reached $€ 213$ billion for the 15 existing members and $€ 22$ billion for the new member countries (2004-2006). The funds allocated to this policy aim account for $35.7 \%$ of the EU budget during 2007-2013. For the next programming period (2014-2020), Structural Funds will focus upon innovation and smart growth specialisation, to meet the goals of the European 2020 Growth Strategy. Given the current constraints on national public funding, this orientation of Funds appears as crucial to fill the gaps on national investments (without substituting them).

Considering the amount of funds involved, as also the persistence of this policy objective for over than 20 years, two issues emerge. First, to what extent the regional policy, more precisely its main financial instrument (Structural Funds), has been effective. Second, to what extent the EU funds have become more effective in promoting growth and reducing the disparities between EU Member countries is also a matter of concern. Indeed, The EU Regional Policy must thus be understood as a process with a large potential for learning and improvement. Despite the wide diversity of studies about the impact of Structural Funds on regional growth, only a few are concerned with the comparison of effects between programming periods. The focus has been put mainly on the effects of the EU financial transfers over growth, rather than on the evolution of the efficiency on the application of such transfers, following the successive changes carried out. The gap is, in part, due to lack of data.

In this study we investigate the existence (or not) of learning effects and efficiency improvements following reforms on Regional Policy, being innovative in this regard. We contribute to the literature in other aspects. First, we use an estimation method robust to cross-sectional correlation. Secondly, we add the most recent programming period to the analysis of learning effects (the two first years, where data is available). Lastly, we consider interaction terms that allow us to understand the possible indirect channels through which Funds may be affecting growth, namely through the relationship with income, innovation or human capital. We also distinguish between Cohesion and Non-Cohesion receivers and search for the existence of diminishing marginal returns on Structural Funds. The study is applied to data from EU regions (EU-12), in the most recent programming periods where data are available. 
In Section 2 we reflect upon the literature on the relationship between European Structural Funds and regional growth. In Section 3 we present the empirical strategy adopted and the results are discussed in section 4 . The last section concludes.

\section{On regional policy and regional growth}

The role of Structural Funds is at the centre of the discussion on the effectiveness of the EU Regional Policy to attain the desired goals of growth, competitiveness, disparities reduction and economic, social and (more recently) territorial cohesion. The way Regional Policy is structured and the interrelationships among different actors at different levels have been widely discussed in the literature, as they are considered to have an impact over the expected results from the financial transfers. There is a multilevel governance regarding Regional Policy, in a top-down fashion and which implies some democracy problems in the Structural Funds system (Olsson 2003). Associated to this is the fact that the national governments' role is not as relevant in the implementation of Regional Policy as it is often declared, with the European Commission taking the leading role, also through audit and control on national and subnational governments (Bachtler and Mendez 2007; Mendez and Bachtler 2011). ${ }^{1}$

Structural Funds are not aimed at redistributing income but at increasing the returns on investment so as to promote faster growth, especially in the periphery. The empirical results on this matter are far from being unanimous. Table 1 summarises the main results from recent studies regarding the impact of EU financial assistance over regional growth.

\section{[TABLE 1]}

It is hard to establish comparisons among the studies due to a variety of reasons. First, the proxy used for Structural Funds differs, the sample of regions included varies, the time period and the estimation method considered are also diverse. ${ }^{2}$ Dall'erba and Le Gallo 2008 found a non-significant impact of EU transfers over growth, whereas

\footnotetext{
${ }^{1}$ For a more detailed discussion on these topics, see also Scharpf (2002) and Barca (2009). To explore further the question of why some regions perform better than others in terms of the quality of government, see Charron et al. (2014).

${ }_{2}$ We only consider studies about European regional growth that include Structural Funds as an explanatory variable.
} 
Cappelen et al. (2003), Puigcerver-Peñalver (2007), Ramajo et al. (2008) and Becker et al. (2010) concluded that financial transfers helped regions to grow faster. Following a different approach, De Freitas et al. (2003), showed that it is indifferent for growth whether a region is eligible as an Objective 1 region (with per capita GDP lower than $75 \%$ of the EU average) or not. Most of the studies, however, get to inconclusive outcomes. Esposti and Bussoletti (2008) and Llussá and Lopes (2014) find limited impacts of Funds over growth. Also, Mohl and Hagen (2010) and Fiaschi et al. (2011) unveil the existence of a territorially uneven impact. Finally, for Rodriguez-Pose and Fratesi (2004) and Rodriguez-Pose and Novak (2013) the European transfers have a positive impact over regional growth conditional on other elements.

Despite the current discussion about the efficiency of Regional Policy, only a small number of empirical studies have analysed the existence of learning effects coming from the application of Structural Funds, following successive changes on the Regional Policy. One of the reasons for such scarcity may lie in the difficulty of finding comparable data. Another one may have to do with the short length of time involved. ${ }^{3}$

One of the mentioned studies on learning effects is that of Cappelen et al. (2003). The authors estimate a cross-section growth model for a sample of 105 regions from the EU9 before the enlargement of the 1990s, in the 1980-1997 period. It follows previous work from the same authors about the existence of three channels of growth: knowledge diffusion (proxied by the initial per capita income), innovation (proxied by R\&D intensity) and complementary factors (proxied by the share of employment in agriculture and industry, physical infrastructure, unemployment rate, population density, and the Funds). By using a temporal dummy capturing the reform of the Funds undertaken in 1988 and combining it with the other variables, the authors conclude that the Funds reorganisation was well succeeded to turn the European policy more efficient.

\footnotetext{
${ }^{3}$ Camagni and Capello (2002) focus on the concept of innovative milieu: given the geographical and relational proximity between firms, the local environment reduces uncertainty, coordination costs and provide the conditions for collective learning (through imitation, collaboration in projects, tacit transfer of knowledge or public/private partnerships). The authors conclude that, for high-tech SME, generally, the collective learning channels are operated by the smallest and more innovative firms and that factor productivity of firms depends positively on collective learning.
} 
Moreover, they estimate the same model for a shorter sample excluding Portuguese, Greek and Spanish regions and by comparing the coefficients in both regressions, they conclude that the impact of the Funds is more pronounced in more developed economies, probably because they possess more developed "social capabilities" to optimise the Funds. Moreover, by using national dummies, the authors conclude that Portugal and Spain benefited greatly from the adhesion to the EU by receiving large amounts of Funds.

Focusing on the Objective 1 regions only (41 NUTS 2), Puigcerver-Peñalver (2007) estimates the impact of Structural Funds over growth during the first two programming periods (1989-2000), using panel data estimated by pooled OLS. The ratio of EU per capita income over that of each region is used to capture catch-up. In addition, the author also uses initial per capita income. Regarding Structural Funds, three alternatives are considered: the ratio of Funds over per capita GDP, the share of Funds on total Funds received by Objective 1 regions and the annual total amount. Moreover, the Funds are also divided by program: ERDF (European Regional Development Fund), ESF (European Social Fund) and EAGGF (European Agricultural Guidance and Guarantee Fund). Apart from these, the author includes the private and public national expenditure in absolute terms and divided by regional GDP. Additionally, interaction terms are considered by combining the variables with the trend. The outcomes indicate that Structural Funds have contributed positively for growth in Objective 1 regions, with the effect being more evident during the first programming period (1989-1993) than the second (1994-2000).

Becker et al. (2010) highlight the impact of EU Structural Funds, namely those destined to Objective 1 regions, on regional performance. The variable of interest is the average annual growth of regional per capita GDP during a given programming period (19891993, 1994-1999 and 2000-2006). The authors apply regression models for fuzzy regression-discontinuity analysis, estimated by OLS and 2SLS. The parameter estimates are not directly comparable, since the number of regions considered differs from one programming period to another. The largest point estimate is observed for 1989-1993 and the smallest, for 1994-1999.

Rodriguez-Pose and Novak (2013) have recently tried to infer about the dynamics on the efficiency of Regional Policy. For that, they analyse 133 European regions during 
the second and third programming periods (1994-1999 and 2000-2006, respectively). For comparison purposes, only Members before 2004 were included. The idea was to check the effect that changes in the definition of the programming periods may have had over growth (namely the reduction of the number of objectives and the greater emphasis on growth and employment rather than on physical infrastructures). For that, they use a neoclassical growth model for panel data and estimate it using heteroscedasticity and autocorrelation-robust Fixed Effects (FE). To control for the existence of spatial autocorrelation, they use the ratio of regional over national income. The explanatory variables include per capita income, relative income, per capita Structural Funds expenditure and (alternative) interaction terms between Funds and national or relative income. In addition, a national corruption index is used, together with regional variables for infrastructures, education and innovation. The variables are lagged once, except the last three, which refer to the current period.

The authors estimate the same model for both subperiods and compare the magnitude and significance of the coefficients, giving special attention to those related to the Funds. None of those coefficients is significant in the 1994-1999 period, contrary to what occurs in 2000-2006, where the Funds have a positive and significant impact. However, this effect depends on the level of national wealth and the relative regional prosperity: the returns from the investment on Funds tend to be higher the richer the country and also the better-off a region is within a given country.

The theoretical explanations for the improvement found in the application of Funds lie in the existence of learning processes, reorientation of priorities, reinforcement of the partnership principle, institutional learning, greater focus in outcomes and improvements in the monitoring of execution.

Also Fiaschi et al. (2011) have contributed to the literature on the learning effects from EU assistance, although their analysis is not over income but on productivity growth. The authors examined three programming periods (1975-1988, 1989-1993 and 19941999) through the inclusion of interactive terms between the periods and the Funds and they conclude that EU transfers contribute positively to productivity growth, being the main effect conveyed by Objective 1 payments. Moreover, the largest impacts were found in 1989-1993 and 1994-1999, i.e, after the structural reform of the Funds and the increase in the EU transfers that followed. 
From a different approach and at the national level, Kyriacou and Roca-Sagalés (2012) show that Structural and Cohesion Funds contributed to decrease regional disparities within EU-Members during the programming periods 1994-1999 and 2000-2006.

Therefore, despite the wide diversity of studies about the impact of Structural Funds on regional growth, only a few consider the differentiated effects between programming periods. The focus has been put mainly on the effects of the EU financial transfers over growth, rather than on improvements in the efficiency on the application of such transfers. Considering the successive changes that have been carried out in the functioning of the Regional Policy this is a matter that deserves further evaluation.

\section{Empirical strategy}

\subsection{Econometric approach}

The neoclassical growth model (Solow 1956) has been the main framework under which growth and convergence issues have been dealt with in the literature due to its greater flexibility.

The original formulation about absolute convergence with decreasing marginal returns to physical capital and exogenous technological progress seems to fit better similar economies sharing the same characteristics. Otherwise, the conditional convergence approach is best suited, relying on variables with increasing marginal returns properties, especially human capital and innovation (Barro and Sala-i-Martin 1992).

Hence, we estimate the augmented version of the neoclassical growth model as was adapted by Caselli et al. (1996) to panel data:

$$
\begin{aligned}
g y_{i, t}= & \alpha_{i}+c_{1} \ln \left(y_{i, t-1}\right)+c_{2} \ln \left(\text { gpop }_{i, t-1}\right)+c_{3} \ln \left(s_{i, t-1}\right)+c_{4} \ln \left(\text { pat }_{i, t-1}\right)+ \\
& +c_{5} \ln \left(h c_{i, t-1}\right)+c_{6} \ln \left(s f_{i, t-1}\right)+u_{i, t}
\end{aligned}
$$

Equation (1) depicts the growth model in its simplest form, without interaction terms. The subscript $i$ refers to the EU12 regions ${ }^{4}$ and $t$ is the time index.

\footnotetext{
${ }^{4}$ The description of the regions considered is in the Appendix I. Austria, Denmark and Italy are excluded for lack of data at the regional level for the entire period. Therefore, their regions are excluded from the
} 
The dependent variable is the annual growth rate of real per capita income $\left(g y_{i, t}\right) .{ }^{5}$ All the explanatory variables appear in logs and are lagged once.

The right-hand side variables are the following: $\ln \left(y_{i, t-1}\right)$, real per capita income; $\ln \left(\right.$ gpop $\left._{i, t-1}\right)$, annual population growth rate; $\ln \left(s_{i, t-1}\right)$, the (interpolated) investment share; $\ln \left(\right.$ pat $\left._{i, t-1}\right)$, innovation proxied by the number of patents per million inhabitants; ${ }^{6}$ $\ln \left(h c_{i, t-1}\right)$, (interpolated) human capital measured by the ratio of population aged 25-64 with tertiary education; and $\ln \left(s f_{i, t-1}\right)$, (interpolated) Structural Funds. ${ }^{7}$

Whenever the coefficient on lagged income is negative and significant, it indicates the existence of conditional convergence $\left(c_{1}<0\right)$. Also, the annual population growth rate is commonly understood as contributing negatively to per capita income growth $\left(\mathrm{c}_{2}<0\right)$ since the available capital must be spread more thinly over population (Mankiw et al. 1992). Physical capital is considered to positively influence growth $\left(c_{3}>0\right)$, due to its impact on the steady-state level of output per capita and hence, on the growth of output - the neoclassical view - or due to spillover effects and economies of scale - the endogenous growth approach (Economidou et al. 2006). We expect both innovation and human capital to play a positive role on regional performance $\left(\mathrm{c}_{4}>0, \mathrm{c}_{5}>0\right)$.

Human capital is understood as a measure of the ability and skills of the labour force. It is commonly evaluated by the level of formal education and it enables the increase of the productivity of physical capital (Lucas 1988). Most of the empirical studies highlight the positive role of human capital for growth (for instance, Ciccone and Papaioannou (2006) and Soukiazis and Antunes (2012) at the country level and Rodriguez-Pose and Crescenzi (2008) at the regional level). In fact, negative and/or statistically insignificant impacts of human capital, especially in panel approaches, are associated to poor quality data and inadequate proxies of human capital (Islam 1995).

regressions of the 1995-1999 programming period. To ensure that we are analyzing the same units along the global period, we discard the same regions for the three programming periods.

${ }^{5}$ For details on the variables, see the Appendix II.

${ }^{6}$ Sedgley (1998) and Mohl and Hagen (2010) are two examples of studies using the patents ratio as a proxy for innovation.

7 We use per capita real Structural Funds, $\ln \left(s f p c_{i, t-1}\right)$, and alternatively, Structural Funds as a percentage of GDP, $\ln \left(s f\right.$ share $\left._{i, t-1}\right)$. Since some values are null, to avoid losing observations we add 1 to the Funds before computing the logarithm. 
The accumulation of technological change is also a key factor for growth, according to authors like Romer (1986) or Di Liberto (2007). ${ }^{8}$ In fact, human capital and sources of technological progress are found to be some of the most important structural factors to differentiate the economies in their growth process. However, they are only translated into faster economic growth if the economies show the "social capability" to benefit from higher standards on education and innovation (Abramovitz 1986).

As regards Structural Funds, the sign of the impact is not clear a priori, given the mixed outcomes from the literature depicted in Sections 3 and $4\left(c_{6}>0\right.$ or $\left.<0\right)$.

\subsection{Data}

We use annual data for the 1995-2009 period. We analyse the performance of 92 EU12 regions in three programming periods (1995-1999, 2000-2006, and 2007-2009).

The growth model is estimated for three subperiods, corresponding to the second, third and fourth programming periods, respectively. The second programming period started in 1994 but we have no data for that year. On the other hand, the fourth programming period is considered only until 2009, due to data availability. The results must thus be read with caution, especially in this case since the time period is too small to allow for strong conclusions.

\subsection{Variables and descriptive analysis}

In the Appendix III we display summary statistics for the main variables used in the estimations, for each of the programming periods. The variables are not in the logarithmic form to ease interpretation.

First of all, the average annual growth rate decreases across the subperiods, being negative in the most recent one. Moreover, the investment share and the patents ratio show higher averages during 2000-2006. Human capital, real per capita income and the Structural Funds averages increase along the programming periods, but for the last two variables we also assist to a marked dispersion, given by the standard deviation. Therefore, together with a deterioration of per capita income growth rates across the

\footnotetext{
${ }^{8}$ See Rodriguez-Pose and Crescenzi (2008) as an example of a study on innovation at the regional level.
} 
subperiods, we also observe higher figures on educational standards and EU financial transfers (both in per capita terms and as a percentage of GDP). In addition, not only the amounts of aid increase but also the dispersion in the distribution. All these elements let us wonder if the Structural Funds are fulfilling the goals of the Regional Policy that aim for economic and social cohesion, regional asymmetries reduction and growth promotion.

\section{Econometric Results}

We estimate the growth model by $\mathrm{FE}^{9}$ with Driscoll and Kraay's correction taking into account the possible existence of residuals correlation not only within but also between groups of individuals (Hoechle 2007). This way, standard errors are robust to general forms of temporal and spatial dependence. In fact, if the common factors responsible for the cross-sectional dependence are unobserved and uncorrelated with the included regressors, the standard panel estimators are consistent although not efficient and the estimated standard errors are biased. One of the possibilities is to use the same estimator and correct the standard errors by following the Driscoll and Kraay's approach (De Hoyos and Sarafidis 2006). ${ }^{10}$

Table 2 displays the results of the estimation of the growth equation with per capita Structural Funds as the proxy for the European financial assistance. It is divided in three sections: columns (1) to (6) display the results for the second programming period (1995-1999); columns (7) to (12) show the outcomes for the third programming period (2000-2006); and columns (13) to (18) present the estimations for the (incomplete) fourth programming period (2007-2009).

For each of the programming periods, we have six alternative equations: the regression without interaction terms is followed by the estimation of the growth model with an

\footnotetext{
${ }^{9}$ It is often more adequate to use FE than RE with aggregated data, in terms of policy analysis (Wooldridge 2009). The regressions were run in Stata 12.

${ }^{10}$ If conversely the unobserved elements are correlated with the included regressors, the FE and RE estimators will be biased and inconsistent, but procedures like Instrumental Variables or Generalised Method of Moments are inconsistent in short dynamic panels. Moreover, finding instruments correlated with the regressors but not with the unobserved components is a difficult task (De Hoyos and Sarafidis 2006).
} 
interaction term between the Structural Funds and income, patents, human capital and the Cohesion dummy. ${ }^{11}$ Lastly, a quadratic term on Structural Funds is added.

\section{[TABLE 2]}

\section{5-1999 (Columns 1 to 6)}

For the second programming period (1995-1999), there is evidence of conditional convergence, given the negative and statistically significant impact of the lagged income coefficient (except in column 2). Only in column (4), when the Funds are interacted with human capital, is possible to obtain convergence and a significant F-test, meaning that the variables are jointly significant for explaining growth. In that case, the Funds impact on growth only indirectly, depending on the level of human capital. More specifically, the returns from European financial aid tend to be greater the higher the human capital level a region possesses.

Generally speaking, these outcomes are in line with much of the literature on the returns of the structural policy intervention during the second programming period, where only a limited or in some cases an insignificant influence of EU transfers on regional growth occurs (Rodriguez-Pose and Fratesi 2004; Dall'erba and Le Gallo 2008; Esposti and Bussoletti 2008).

\section{0-2006 (Columns 7 to 12)}

For the third programming period (2000-2006), the F-test indicates that all the estimations are reasonable in terms of joint significance. The $\mathrm{R}^{2}$ is higher during this period. The convergence coefficient is always significant, higher in magnitude than in the previous period and negative, indicating conditional convergence. The investment share, the patents ratio and the education level are all positively affecting growth, as expected, though not always significantly. The coefficient on the annual population growth rate is negative although not significant, a common finding in the literature.

\footnotetext{
${ }^{11}$ Although the Cohesion countries change throughout the period, we create a dummy variable (labeled Cohesion) equal to 1 for regions from Portugal, Greece, Spain and Ireland. The idea is to analyse whether this group, which has received large amounts of financial aid, has succeeded in reflecting it into faster growth.
} 
Regarding our variable of interest, the Funds affect growth positively when only direct effects are accounted for (column 7).

From combining the Funds with income (column 8) we observe that apparently they are affecting growth positively in wealthier areas:

$$
\begin{gathered}
\frac{\partial g y_{t}}{\partial \ln \left(s f p c_{t-1}\right)}>0 \Leftrightarrow-0.1528+0.0157 \ln \left(y_{t-1}\right)>0 \Leftrightarrow \\
\Leftrightarrow \ln \left(y_{t-1}\right)>9.732 \Leftrightarrow y_{t-1}>16856.37
\end{gathered}
$$

Our outcome confirms the previous findings by Cappelen et al. (2003) and RodriguezPose and Novak (2013) about the economic effects of European transfers being greater in more developed areas. 18 regions display figures lower than the indicated threshold for several years, resulting on 109 observations below the limit on per capita income. Only two out of the ten Greek regions (Sterea Ellada and Notio Aigaio) show per capita incomes higher than 16856.37; regarding the Spanish regions, 6 out of 17 do not fulfil the limit on per capita income (Galicia, Principado de Asturias, Castilla-la Mancha, Extremadura, Andalucia and Región de Murcia). Norte, Algarve, Centro and Alentejo (Portuguese regions) also fall behind this threshold on income. In these cases, the investment policy from the EU may not be helping them to growth faster.

In column 9 we analyse whether the impact of Funds over growth can be occurring through the interaction with the patents ratio:

$$
\begin{gathered}
\frac{\partial g y_{t}}{\partial \ln \left(s f p c_{t-1}\right)}>0 \Leftrightarrow-0.0056+0.0029 \ln \left(p a t_{t-1}\right)>0 \Leftrightarrow \\
\Leftrightarrow \ln \left(p a t_{t-1}\right)>1.931 \Leftrightarrow p a t_{t-1}>6.897
\end{gathered}
$$

The Structural Funds are affecting growth positively only in more innovative regions. The Finnish region of Äland as well as some Greek (Anatoliki Makedonia, Kentriki Makedonia, Thessalia, Ipeiros, Dytiki Ellada, Sterea Ellada, Peloponnisos, Notio Aigaio and Kriti), Portuguese (Norte, Algarve, Centro, Lisboa and Alentejo) and Spanish (Galicia, Principado de Asturias, Cantabria, La Rioja, Castilla-la Mancha, Extremadura, Illes Balears, Andalucia, Región de Murcia and Canarias) regions 
display innovative levels lower than the indicated limit, showing that in these regions (in some years) the Funds are not fulfilling their goal of promoting growth and cohesion. Given that innovation and income levels are generally positively correlated, this outcome demonstrates that the returns of EU financial assistance are higher in more favoured areas.

By combining Funds with human capital (column 10), we perceive that Structural Funds are most effective in promoting growth in those areas showing higher education standards:

$$
\begin{gathered}
\frac{\partial g y_{t}}{\partial \ln \left(s f p c_{t-1}\right)}>0 \Leftrightarrow-0.0435+0.0154 \ln \left(h c_{t-1}\right)>0 \Leftrightarrow \\
\Leftrightarrow \ln \left(h c_{t-1}\right)>2.825 \Leftrightarrow h c_{t-1}>16.855
\end{gathered}
$$

Our outcome confirms the recent argument from Becker (2012) about the fact that low education levels prevent regions from improving their absorptive capacity and consequently from turning transfers into additional growth. Saarland and SachsenAnhalt (Germany), Anatoliki Makedonia, Thessalia, Ipeiros, Dytiki Ellada, Sterea Ellada, Peloponnisos, Notio Aigaio and Kriti (Greece), Castilla-la Mancha and Extremadura (Spain), Champagne-Ardenne, Picardie, Centre, Bourgogne, Nord - Pasde-Calais, Franche-Comté, Poitou-Charentes and Limousin (France), Norte, Algarve, Centro, Lisboa and Alentejo (Portugal) and Luxembourg do not attain this threshold in some years.

In column (11) our goal was to understand whether Portugal, Spain, Greece and Ireland, generally known as the Cohesion group, benefited more in terms of growth from receiving large amounts of financial aid from the EU (both Structural and Cohesion Funds). The coefficient on the interaction term (-0.0085) indicates us the difference on the expected growth between Cohesion and Non-Cohesion regions. Thus, in the regions of the Cohesion group, the impact of the European aid over growth is marginal, ${ }^{12}$ whereas in the other regions the impact is 0.008 . It appears that support is least efficient where it is most needed, as Cappelen et al. (2003) had already stated.

\footnotetext{
${ }^{12}$ In regions from the Cohesion group, the impact of Funds is given by: $0.008-0.0085=-0.0005$.
} 
In column (12), we tried to ascertain the existence of diminishing marginal effects, by including a quadratic term on Funds, but no reasonable results emerged.

\section{$\underline{\text { 2007-2009 (Columns } 13 \text { to } 18 \text { ) }}$}

The fourth programming period is only partially captured over 2007-2009, evidently short for deriving robust conclusions for the whole period. However, we opted for displaying the results, for evaluation purposes. Moreover, by comparing coefficients and statistical significance, we may check whether tendencies detected during the previous programming period are maintained.

Overall, there are no signs of conditional convergence, what can be explained by the short time period considered. Another relevant note has to do with the negative impact of human capital, somehow unexpected.

Regarding Funds, they have a positive impact on growth (column 13) and are well combined with income (column 14) and human capital (column 16), revealing that the returns from financial aid are higher in richer regions with higher levels of education. Comparing these outcomes with those from the previous period (columns 8 and 10, respectively), some of the regions that in 2000-2006 were behind the threshold that enabled a positive impact of Funds over growth remain in the same situation during the fourth programming period. This fact calls the attention to the way Funds are being allocated and raises efficiency issues: on the one hand, financial transfers affect growth positively in richer and high-educated regions and, on the other hand, some regions did not manage to improve their income and education standards to benefit from a positive impact of Funds over growth.

Once more, belonging to the Cohesion group has a negative impact on growth $(-0.0509)$ when compared to Non-Cohesion regions (column 17). Although this result must be read with caution, it alerts for the fact that those regions that have been receiving large transfers are not being able to turn those financial sums into faster growth, thus questioning their effectiveness.

Finally, in column (18) we observe that in the 2007-2009 period there is an inverted Urelationship between Funds and regional growth, showing us that financial assistance has a positive effect on growth but at a decreasing marginal rate. For annual per capita 
Funds transfers higher than $270.72 €$, each additional Euro received will result in lower growth rates. Apart from the German region of Mecklenburg-Vorpommern (DE8), all the others that receive more than the indicated limit are Greek (Anatoliki Makedonia, Kentriki Makedonia, Thessalia, Ipeiros, Dytiki Ellada, Sterea Ellada, Peloponnisos, Notio Aigaio, Kriti) Spanish (La Rioja) and Portuguese (Norte, Algarve, Centro and Alentejo) regions, which are part of the Cohesion group (in column 17 we had already concluded that Cohesion regions did not grow faster).

In Table 3 we use the share of Funds on GDP as a proxy for the regional financial assistance.

\section{[TABLE 3]}

From Table 3 we observe that, in the first place, both in 1995-1999 and 2007-2009 there are no signs of conditional convergence since the coefficient on lagged income is never significant. The investment share and the population growth rate are also insignificant, despite displaying the expected signs. In addition, the patents ratio is always significant. The human capital is always significant in 2007-2009 (although with a negative sign), whereas in the 1995-1999 period it is only significant in the first column. However, the regressions are not satisfactory in columns 1, 4, 13 and 17 (F-test statistically insignificant) and thus we will not comment on these results.

\section{5-1999 (Columns 1 to 6)}

For this subperiod, the only reasonable results come from columns 2 and 5. However, there are no signs of conditional convergence. ${ }^{13}$ From the results of column 2, we observe that the Funds always have a positive impact over growth, since all the regions have income levels higher than the limit enabling such a positive effect. From column 5, we observe that Structural Funds have a positive impact on growth, although higher in Non-Cohesion regions $(0.1327)$ than in the Cohesion group $(0.1327-0.1136=0.0191)$.

\section{0-2006 (Columns 7 to 12)}

\footnotetext{
13 There is some empirical evidence showing that the tendency towards convergence stopped in the beginning of the 1980s. Moreover, convergence seemed to have occurred mostly at the national than at the regional level (Cappelen et al. 2003).
} 
The lagged income is always negative and significant, indicating the existence of conditional convergence. The investment share is insignificant (except in columns 8 and 11), as well as the annual population growth rate (except in column 12), although both display the expected signs. Both the innovation proxy and human capital are positive and significant (the exception being in column 9 for the patents ratio). Regarding Structural Funds, the coefficient is always significant, except in column 7, where only direct effects are captured.

Proceeding in the analysis about the links through which Funds may indirectly affect growth, we conclude that the returns from financial assistance are higher in richer regions (column 8). Some Greek, Spanish and Portuguese regions display income levels lower than the one providing a positive effect of Funds over growth.

In addition, the impact of Funds is positive in more innovative regions (column 9). Like in Table 2, some Greek, Spanish and Portuguese regions, as well as the Finnish Äland region, lay behind the innovation limit that enables a positive impact of Funds on growth.

Our outcomes also demonstrate that the returns from Funds are higher in regions showing higher levels of human capital (column 10). With education levels lower than the limit are some German, French, Portuguese, Spanish and Greek regions and thus in those cases the Funds are not playing a positive role on growth. ${ }^{14}$

From column 11, when Funds are interacted with the Cohesion dummy, we infer that the impact of Funds on Non-Cohesion regions is 0.0409 , whereas in the Cohesion group it is negative (of about -0.013 ).

Finally, by including a quadratic term on Structural Funds we observe that although they exert a positive impact on growth, for shares over than $1.9 \%$ of GDP, the effect changes sign. In fact, only some Greek, Spanish and Portuguese regions surpass this limit, raising doubts about the efficiency of the application of such transfers. Combining the outcomes with those from the previous column, although regions from these countries are receiving large amounts of financial aid from the EU, they have not been

\footnotetext{
${ }^{14}$ Although Luxembourg is also below the threshold in 2000-2003, its figures are rather close to the limit (except in 2003).
} 
able to transform it into faster growth. This may be a sign of the lack of capacity to turn transfers into additional growth. Our outcome is in line with other empirical results. Becker (2012) pointed the maximum desirable level of transfer intensity to be of $1.3 \%$ of regional GDP. Moreover, Kyriacou and Roca-Sagalés (2012) indicated that for transfer intensities above $1.6 \%$ of GDP, additional Funds lead to increased national disparities.

\section{$\underline{2007-2009 \text { (Columns } 13 \text { to } 18 \text { ) }}$}

For the fourth programming period, the impact of Funds over growth is positive in richer regions (column 14), has had been previously concluded. Compared to the 20002006 period, some Spanish regions were able to increase their income level in order to be part of the group where the impact from Funds over growth is positive. Conversely, Greek and Portuguese regions did not manage to improve their position in this regard.

From the combination of Funds with human capital we conclude that in this period the returns from Funds are higher in regions with higher levels of human capital (column 16). Compared to the 2000-2006 period, the Spanish regions as well as Luxembourg leave the group of regions for which the impact of Funds is not positive.

In the last column (18), the quadratic term for the Funds indicates us that its impact over growth is positive up to the limit share of 3\% of GDP. For higher shares the impact of the Funds turns out to be negative. Some Greek and Portuguese regions display higher shares for this period, ranging from 3 to $6.2 \%$. Our outcome shows that higher shares do not conduct to faster growth per se, thus justifying plentifully the ceiling of $4 \%$ established in the 1999 Berlin Summit.

\section{Conclusion}

The European Regional Policy has increased in relevance along the years and has been progressively representing a higher share of the EU budget, reaching about $35.7 \%$ in the fourth programming period (2007-2013). For the next programming period, the Structural Funds are perceived as extremely important for helping regions to achieve smart, sustainable and inclusive growth, as defined in the Agenda 2020. 
At the empirical level there is no consensus about the role of the Regional Policy for growth and only a few studies addressed the evolution of the efficiency on the application of the Funds. Given the reforms that have been carried out over time, and importance of policy learning for the future, this is a matter that deserves further investigation.

From the estimation of the growth model robust to the existence of cross-sectional dependence, we concentrate on the results of our variable of interest - the Structural Funds (both in per capita terms and as a percentage of GDP).

The first visible outcome is that the most solid results come from the 2000-2006 programming period.

Overall, funds have a positive impact on growth in richer, high-educated and more innovative regions. In addition, regions from the Cohesion group are not able to convert the large amount of transfers received into faster growth. More funds do not necessarily mean more growth.

The tendency observed in 2000-2006 is confirmed in the more recent programming period, although we only cover the first years (2007-2009).

Therefore, although the goals of Regional Policy have to do with growth promotion and regional disparities reduction to guarantee cohesion in the European territory, we have seen that, in general terms, only richer regions with higher standards on education and innovation assist to a positive impact of financial aid over growth. This fact highlights that for Regional Policy to be successful it is required that regions demonstrate a minimum level (whether in terms of per capita income level, human capital or innovation) to be able to turn financial aid into additional growth. An alternative explanation lies in the fact that richer economies may have greater comparative advantages, thus justifying the higher returns from Regional Policy in those areas. Nevertheless, the explanations presented may also be regarded as criticisms to the Regional Policy functioning.

Apparently, for the Funds to be efficient in promoting growth and reduce asymmetries within European regions, it is essential to combine financial transfers with structural policies that improve the "social capability" of the more disadvantaged areas, so that 
they can have the tools to promote sustainable catch-up towards the EU average. More specifically, policies oriented towards education levels improvement and promotion (and protection) of the innovative activity should be combined and coordinated with the EU Regional Policy, in order to guarantee that financial transfers are efficiently and successfully allocated. Moreover, tighter supervision and encouragement of incentives to award best practices could also help to achieve the desired goals of the EU Regional Policy.

Our conclusions regarding the need to design policies intended to promote education levels and innovation in order to ensure the success of Regional Policy find support in the current programming period 2014-2020, which privileges the objectives defined in the Europe 2020 Growth Strategy: employment, R\&D, climate change and environment, education, poverty and social exclusion. Moreover, the simplification of procedures, the decentralization of the process and a greater role to agents at the local level are goals for 2014-2020, trying to overcome the critiques on the lack of democratization of the funding system and the modest role of agencies at the national and sub-national levels. The final aim is that Regional Policy can effectively and consistently contribute to a sustained and balanced growth among European regions. 


\section{Appendix I - List of the regions included}

The choice on the level of regional disaggregation (NUTS) ${ }^{15}$ for each country depended on the availability of data for Structural Funds. The 92 regions considered are the following - according to European Commission's (2007) codes:

\begin{tabular}{|c|c|}
\hline Member-State & Regions \\
\hline Belgium (3 NUTS 1): & $\begin{array}{l}\text { Région de Bruxelles-Capitale (BE1), Vlaams } \\
\text { Gewest (BE2), Région Wallonne (BE3) }\end{array}$ \\
\hline France (19 NUTS 2): & $\begin{array}{l}\text { Île de France (FR10), Champagne-Ardenne } \\
\text { (FR21), Picardie (FR 22), Centre (FR 24), } \\
\text { Bourgogne (FR 26), Nord-Pas-de-Calais (FR 30), } \\
\text { Lorraine (FR 41), Alsace (FR 42), Franche-Comté } \\
\text { (FR 43), Pays-de-la-Loire (FR 51), Bretagne (FR } \\
\text { 52), Poitou-Charentes (FR 53), Aquitaine (FR 61), } \\
\text { Midi-Pyrénées (FR 62), Limousin (FR 63), Rhône- } \\
\text { Alpes(FR 71), Auvergne (FR 72), Languedoc- } \\
\text { Roussillon (FR 81), Provence-Alpes-Côte d'Azur } \\
\text { (FR 82) }\end{array}$ \\
\hline Finland (2 NUTS 1): & Manner-Suomi (FI1), Åland (FI2) \\
\hline Germany (16 NUTS 1): & $\begin{array}{l}\text { Baden-Württemberg (DE1), Bayern (DE2), Berlin } \\
\text { (DE3), Brandenburg (DE4), } \\
\text { Bremen (DE5), Hamburg (DE6), Hessen (DE7), } \\
\text { Mecklenburg-Vorpommern (DE8), Niedersachsen } \\
\text { (DE9), Nordrhein-Westfalen (DEA), Rheinland- } \\
\text { Pfalz (DEB), Saarland (DEC), Sachsen (DED), } \\
\text { Sachsen-Anhalt (DEE), Schleswig-Holstein } \\
\text { (DEF), Thüringen (DEG) }\end{array}$ \\
\hline Greece (10 NUTS 2): & $\begin{array}{l}\text { Anatoliki Makedonia, Thraki (GR11), Kentriki } \\
\text { Makedonia (GR12), Thessalia (GR14), Ipeiros } \\
\text { (GR21), Dytiki Ellada (GR23), Sterea Ellada } \\
\text { (GR24), Peloponnisos (GR25), Attiki (GR30), } \\
\text { Notio Aigaio (GR42), Kriti (GR43) }\end{array}$ \\
\hline Ireland (1 NUTS 1):* & Ireland (IE) \\
\hline Luxembourg (1 NUTS 2): ${ }^{*}$ & Luxembourg (LU) \\
\hline Netherlands (4 NUTS 1): & Noord-Nederland (NL1), Oost-Nederland (NL2), \\
\hline
\end{tabular}

${ }^{15}$ NUTS is a territorial classification from the European Commission, standing for "Nomenclature des Unités Territoriales Statistiques". 


\begin{tabular}{|c|c|}
\hline & West-Nederland (NL3), Zuid-Nederland (NL4) \\
\hline Portugal (5 NUTS 2): & $\begin{array}{l}\text { Norte (PT11), Algarve (PT15), Centro (PT16), } \\
\text { Lisboa (PT17), Alentejo (PT18) }\end{array}$ \\
\hline Spain (17 NUTS 2): & 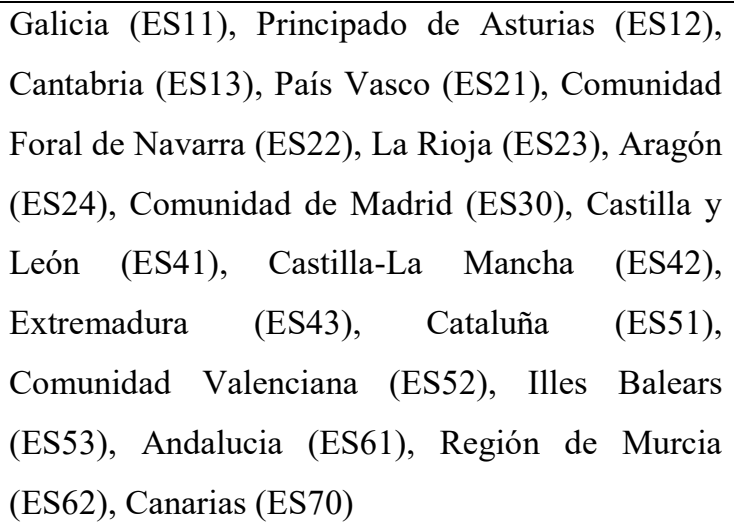 \\
\hline Sweden (2 NUTS 1): & Södra Sverige (SE2), Norra Sverige (SE3) \\
\hline United Kingdom (12 NUTS 1): & $\begin{array}{l}\text { North East (UKC), North West (UKD), Yorkshire } \\
\text { and the Humber (UKE), East Midlands (UKF), } \\
\text { West Midlands (UKG), East of England (UKH), } \\
\text { London (UKI), South East (UKJ), South West } \\
\text { (UKK), Wales (UKL), Scotland (UKM), Northern } \\
\text { Ireland (UKN) }\end{array}$ \\
\hline
\end{tabular}

* The NUTS0 classification coincides with the NUTS1. ${ }^{*}$ The territorial categories NUTS0, NUTS1 and NUTS2 are identical.

\section{Appendix II - Description of the variables and data sources}

- $y_{i, t}-$ Real per capita Gross Domestic Product (GDP) (Euros per inhabitant)

Computed by the authors using data on: (i) GDP at current market prices (Million euro (from 1.1.1999)/Million ECU (up to 31.12.1998)), (ii) Price deflator GDP at market prices (national currency; annual percentage change) and (iii) Annual average population (1 000$)$.

Data Sources: (i) Eurostat, Regional Economic Statistics (data extracted on $6^{\text {th }}$ November 2012); (ii) European Commission (2011) - Knowing the base year $(2005=100)$, we computed the annual national GDP deflator and used it to divide the regional current GDP. Given that regional price indexes are not available, we converted nominal into real figures using national GDP deflator assuming that for each region of a given country, the price index is the same; (iii) Eurostat, Regional Demographic Statistics (data extracted on $20^{\text {th }}$ November 2012). 
- $g y_{i, t}$ - Annual growth rate of real per capita GDP (annual logarithmic difference of real per capita GDP)

- gpop $_{i, t}-$ Annual growth rate of population

Computed by the authors using data on "Annual average population $\left(\begin{array}{ll}1 & 000\end{array}\right)$ ". To the annual logarithmic difference of population we added 5\%, to account for the rate of (human and physical) capital depreciation and the rate of technological progress.

Data Source: Eurostat, Regional Demographic Statistics (data extracted on $20^{\text {th }}$ November 2012).

- $s_{i, t}-$ (Interpolated) Investment share (\%)

Computed by the authors using data on: (i) Gross fixed capital formation (Million euro (from 1.1.1999)/Million ECU (up to 31.12.1998)) and (ii) GDP at current market prices (Million euro (from 1.1.1999)/Million ECU (up to 31.12.1998)).

Data Source: (i) and (ii) Eurostat, Regional Economic Statistics $h c_{i, t}-($ Interpolated) Human capital (\%)

Persons aged 24-65 years with tertiary education attainment

Data Source: Eurostat, Regional Education Statistics (data extracted on $6^{\text {th }}$ November 2012)

- pat $_{i, t}$-Patent applications to the European Patents Office (EPO) by priority year - Total (per million of inhabitants)

Computed by the authors using data on: (i) Number of patent applications to the EPO by priority year and (ii) Annual average population (1 000).

Data Sources: (i) Eurostat, Regional Science and Technology Statistics (data extracted on $16^{\text {th }}$ January 2013) and (ii) Eurostat, Regional Demographic Statistics.

- $\quad s f p c_{i, t}$-(Interpolated) Real per capita Structural Funds (Euros per inhabitant) 
Computed by the authors using data on: (i) payments for 1995-1998; (ii) calculation of payments for 1999 as the difference between commitments and payments in 1994-1998; (iii) payments for 2000-2009; (iv) Price deflator GDP at market prices (national currency; annual percentage change) and (v) Annual average population (1 000).

Data Sources: (i) European Commission (1996; 1997; 1998; 1999); (ii) European Commission (1999); (iii) European Commission - DG Regional and Urban Policy; (iv) European Commission (2011) and (v) Eurostat, Regional Demographic Statistics.

- $s$ share $_{i, t}$-(Interpolated) Structural Funds share over GDP (\%)

Computed by the authors using data on: (i) payments for 1995-1998; (ii) calculation of payments for 1999 as the difference between commitments and payments in 1994-1998; (iii) payments for 2000-2009; (iv) GDP at current market prices (Million euro (from 1.1.1999)/Million ECU (up to 31.12.1998))

Data Sources: (i) European Commission (1996; 1997; 1998; 1999); (ii) European Commission (1999); (iii) European Commission - DG Regional and Urban Policy; (iv) Eurostat, Regional Economic Statistics.

For the years 1995-1998, data on Structural Funds payments was collected from the European Commission's annual Reports (European Commission, 1996; 1997; 1998; 1999). For 1999, we computed the payments as the residual difference between commitments and payments in the $1994-98$ period. ${ }^{16}$

From 2000 onwards, we relied on data sent on $12^{\text {th }}$ December 2012 by the European Commission - DG Regional and Urban Policy, following a formal request. The estimated payments for 2000-2006 refer to the programmes ERDF, ESF, EAGGF, FIFG (Financial Instrument for Fisheries Guidance) and Cohesion Fund. For 2007-2013, payments concern funds received under ERDF, ESF and the Cohesion Fund.

\footnotetext{
${ }^{16}$ We could not successfully download the European Commission's $11^{\text {th }}$ Annual Report on the Structural Funds 1999 (published in 2000), from:

http://ec.europa.eu/regional_policy/sources/docoffic/official/repor_en.htm.
} 


\section{Appendix III - Descriptive statistics}

\begin{tabular}{|c|c|c|c|c|c|c|c|c|c|c|c|c|c|c|c|}
\hline & \multicolumn{5}{|c|}{ 1995-1999 } & \multicolumn{5}{|c|}{$2000-2006$} & \multicolumn{5}{|c|}{ 2007-2009 } \\
\hline Variable & Obs & Mean & Std. Der. & Min & Max & Obs & Mean & Std. Dev. & Min & Max & Obs & Mean & Std. Dev. & Min & Max \\
\hline gy & 368 & 0.028 & 0.041 & -0.059 & 0.207 & 644 & 0.017 & 0.029 & -0.138 & 0.138 & 276 & -0.022 & 0.058 & -0.203 & 0.084 \\
\hline $\mathrm{y}$ & 460 & 21202.630 & 7439.188 & 10323.690 & 54355.240 & 644 & 24282.040 & 8747.132 & 11049.720 & 67266.330 & 276 & 24960.940 & 9236.022 & 11633.410 & 70658.050 \\
\hline gpop & 460 & 0.053 & 0.005 & 0.035 & 0.078 & 644 & 0.056 & 0.007 & 0.037 & 0.083 & 276 & 0.055 & 0.007 & 0.038 & 0.079 \\
\hline $\mathrm{s}$ & 457 & 20.358 & 7.353 & 2.266 & 53.090 & 644 & 21.411 & 5.929 & 9.334 & 44.084 & 169 & 20.780 & 6.668 & 10.179 & 48.211 \\
\hline pat & 437 & 75.158 & 83.887 & 0.219 & 479.252 & 627 & 96.811 & 109.846 & 0.089 & 737.529 & 268 & 73.758 & 86.884 & 0.230 & 557.358 \\
\hline $\mathrm{hc}$ & 460 & 19.653 & 7.979 & 0.500 & 45.500 & 644 & 23.221 & 6.799 & 5.200 & 41.800 & 276 & 26.486 & 6.814 & 10.800 & 43.700 \\
\hline sfpc & 460 & 62.854 & 75.789 & 0.000 & 406.868 & 644 & 100.381 & 122.989 & 0.514 & 652.261 & 276 & 109.486 & 156.189 & 5.501 & 825.490 \\
\hline sfshare & 460 & 0.389 & 0.513 & 0.000 & 3.309 & 644 & 0.590 & 0.874 & 0.000 & 5.066 & 276 & 0.631 & 1.094 & 0.004 & 6.225 \\
\hline
\end{tabular}




\section{References}

Abramovitz M (1986) Catching-up, forging ahead and falling behind. J Econ History 46 (2): $385-406$.

Bachtler J, Mendez C (2007) Who governs EU Cohesion Policy? Deconstructing the Reforms of the Structural Funds. Journal of Common Market Studies, 45(3): 535-564.

Barca, F. (2009) An agenda for a reformed cohesion policy: a place-based approach to meeting European Union challenges and expectations, Report to DG Regional Policy, Brussels.

Barro R, Sala-i-Martin X (1992) Convergence, Journal of Political Economy, 100(2): 223-251.

Becker S (2012) EU Structural Funds: do they generate more growth? The CAGEChatham House Series, No. 3, December, The Royal Institute of International Affairs, 1-12. (www.warwick.ac.uk/go/cage)

Becker S, Egger P, von Elrich M (2010) Going NUTS: the effect of EU Structural Funds on regional performance. J Public Econ 94: 578-590.

Camagni R, Capello R (2002) Milieux innovateurs and collective learning: from concepts to measurement in Acs Z, de Groot H, Nijkamp P (eds) The Emergence of the Knowledge Economy, Springer Berlin Heidelberg, 15-45.

Cappelen A, Castellacci F, Fagerberg J, Verspagen B (2003) The impact of EU regional support on growth and convergence in the European Union. J Common Mark Stud 41(4): 621-644.

Caselli F, Esquivel G, Lefort F (1996) Reopening the convergence debate: a new look at the cross-country growth empirics. J Econ Growth 1 (3): 363-389.

Charron N, Dijkstra L, Lapuente V (2014) Regional governance matters: quality of government within European Union member states, Regional Studies 48(1): 68-90.

Ciccone A, Papaioannou E (2006) Human capital, the structure of production and growth, Working Paper Series 623, European Cent Bank. 
Crescenzi R, Rodriguez-Pose A (2008) Infrastructure endowment and investment as determinants of regional growth in the European Union. European Invest Bank Pap 13 (2): 66-101.

Dall'erba S, Le Gallo J (2008) Regional convergence and the impact of Structural Funds over 1989-1999: a spatial econometric analysis. Pap Reg Sci 87(2): 219-244.

De Freitas M, Pereira F, Torres F (2003) Convergence among EU regions, 1990-2001: Quality of national institutions and "Objective 1" status. Intereconomics 38(5): 270275.

De Hoyos R, Sarafidis V (2006) Testing for cross-sectional dependence in panel-data models. The Stata J 6(4): 482-496.

Di Liberto A (2007) Convergence and divergence in neoclassical growth models with human capital, Econ Pol, Società editrice il Mulino, 2: 289-322 .

Economidou C, Lei V, Netz J (2006) International integration and growth: a further investigation on developing countries. Int Adv Econ Res 12: 435-448.

Esposti R, Bussoletti S (2008) The impact of Objective 1 Funds on regional growth convergence in the EU: a panel data approach. Reg Stud 42(2): 159-173.

European Commission (1996) $7^{\text {th }}$ Annual Report on the Structural Funds 1995, Brussels.

European Commission (1997) $8^{\text {th }}$ Annual Report on the Structural Funds 1996, Brussels.

European Commission (1998) $9^{\text {th }}$ Annual Report on the Structural Funds 1997, Brussels.

European Commission (1999) $10^{\text {th }}$ Annual Report on the Structural Funds 1998, Brussels.

European Commission (2007). Commission Regulation (EC) No. 105/2007, Official Journal of the European Union L 39, 1 February, Brussels. 
European Commission (2011). Statistical Annex of the European Economy, Directorate General Economic and Financial Affairs, Spring, Brussels.

(http://ec.europa.eu/economy finance/publications/european economy/2011/2011-saspring en.htm)

Fiaschi D, Lavezzi A, Parenti A (2011) Productivity growth across European regions: the impact of Structural and Cohesion Funds, 25 November 2011. (Paper presented at the $50^{\text {th }}$ European Congress of the Regional Science Association International, Jönköping, Sweden, August 2010).

http://www.unipa.it/ mario.lavezzi/papers/SCF ProductivityGrowth spat 05.pdf

Hoechle D (2007) Robust standard errors for panel regressions with cross-sectional dependence. The Stata J 7(3): 281-312.

Islam N (1995) Growth empirics: a panel data approach. Q J Econ 110(4): 1127-1171.

Kyriacou A, Roca-Sagalés O (2012) The impact of EU Structural Funds on regional disparities within member states. Environ Plan C: Gov Policy 30(2): 267-281.

Lucas R (1988). On the mechanics of economic development. J Monet Econ 22: 3-42.

Llussá F, Lopes J (2014). Regional growth in Europe: the role of European and national policies, Journal of Policy Modeling.

Mankiw G, Romer D, Weil D (1992). A contribution to the empirics of economic growth. Q J Econ 107(2): 407-437.

Mendez C, Bachtler J (2011) Administrative reform and unintended consequences: an assessment of the EU Cohesion policy "audit explosion". Journal of European Public Policy 18(5): 746-765.

Mohl P, Hagen T (2010). Do EU Structural Funds promote regional growth? New evidence from various panel data approaches. Reg Sci Urban Econ 40: 353-365.

Olsson J (2003) Democracy paradoxes in multi-level governance: theorizing on structural fund system research. Journal of European Public Policy 10(2) 283-300. 
Puigcerver-Peñalver M (2007) The impact of Structural Funds Policy on European regions' growth. A theoretical and empirical approach. European J Comparative Econ 4 (2): 179-208.

Ramajo J, Márquez M, Hewings G, Salinas M (2008) Spatial heterogeneity and interregional spillovers in the European Union: do cohesion policies encourage convergence across regions? European Econ Rev 52: 551-567.

Rodriguez-Pose A, Crescenzi R (2008) R\&D, spillovers, innovation systems and the genesis of regional growth in Europe, Reg Stud 42(1): 51-67.

Rodriguez-Pose A, Fratesi U (2004) Between development and social policies: the impact of European Structural Funds in Objective 1 regions. Reg Stud 38(1): 97-113.

Rodriguez-Pose A, Novak K (2013) Learning processes and economic returns in European Cohesion Policy. Investigaciones Regionales 25(1):7-26.

Romer P (1986) Increasing returns and long-run growth. J Polit Econ 94(5): 1002-1037.

Scharpf F (2002) Legitimate diversity: the new challenge of European integration. Les Cahiers européens de Sciences Po, $\mathrm{n}^{\circ} 01$ Paris: Centre d'études européennes at Sciences Po.

Sedgley N (1998) Technology gaps, economic growth and convergence across US states. Appl Econ Lett 5: 55-59.

Solow R (1956) A contribution to the theory of economic growth. Q J Econ 70(1): 6594.

Soukiazis E, Antunes M (2012) Foreign trade, human capital and economic growth: An empirical approach for the European Union countries. J Intern Trade Econ Dev 21(1): 324.

Wooldridge J (2009) Introductory Econometrics - A modern approach. South-Western CENGAGE Learning ( $4^{\text {th }}$ edition). 


\section{Table 1 Comparative studies on the relevance of Structural Funds for regional growth}

\begin{tabular}{|c|c|c|c|c|c|}
\hline Study & Impact of Structural Funds (SF) on economic growth & Proxy for SF & Period & Sample & Method \\
\hline Llussá and Lopes (2014) & $\begin{array}{l}\text { Structural policies tend to increase convergence inside the } \\
\text { Member States but are ineffective fostering regional } \\
\text { convergence across the EU. }\end{array}$ & $\begin{array}{l}\text { Dummies }=1 \text { if the } \\
\text { region is eligible for } \\
\text { Obj1, Obj } 2 \text { and } \mathrm{Obj} \\
5 \mathrm{~b}\end{array}$ & 1989-1999 & $\begin{array}{l}194 \text { NUTS2 } \\
\text { regions (EU 14) }\end{array}$ & Panel: OLS \\
\hline Rodriguez-Pose and Novak (2013) & $\begin{array}{l}\text { Improvement in the returns of investment in SF between } \\
\text { the second and third programming periods. The returns are } \\
\text { higher in richer countries and better-off regions within a } \\
\text { country. }\end{array}$ & $\begin{array}{c}\text { Obj1, 2, 5b and } 6 \\
\text { payments per capita }\end{array}$ & $\begin{array}{l}1994-1999, \\
2000-2006\end{array}$ & $\begin{array}{l}133 \text { NUTS1-2 } \\
\text { regions (EU 15) }\end{array}$ & $\begin{array}{l}\text { Panel: Het and AR } \\
\text { robust FE }\end{array}$ \\
\hline Fiaschi et al. (2011) & $\begin{array}{l}\text { The effect of SF on productivity growth is positive, but the } \\
\text { main effect is put forth by Obj } 1 \text { funds. }\end{array}$ & $\begin{array}{l}\text { Commitments and } \\
\text { payments (for 1994- } \\
\text { 99) (\% GVA) }\end{array}$ & $1980-2002$ & $\begin{array}{l}173 \text { NUTS2 } \\
\text { regions (EU 12) }\end{array}$ & $\begin{array}{l}\text { Cross-section: } \\
\text { Spatial Durbin } \\
\text { model; Robust OLS }\end{array}$ \\
\hline Mohl and Hagen (2010) & Only Obj1 payments promote regional growth. & $\begin{array}{c}\text { Obj } 1,2 \text { and } 3 \\
\text { payments per capita }\end{array}$ & $1995-2005$ & $\begin{array}{l}126 \text { NUTS1-2 } \\
\text { regions (EU 14) }\end{array}$ & $\begin{array}{c}\text { Panel: FE with } \\
\text { Driscoll and Kraay } \\
\text { correction; SYS- } \\
\text { GMM; ML (FE } \\
\text { spatial lag model) }\end{array}$ \\
\hline Becker et al. (2010) & $\begin{array}{c}\text { Positive per capita growth effects of Obj1 transfers but no } \\
\text { employment growth transfers. }\end{array}$ & $\begin{array}{l}\text { Dummy }=1 \text { for } \\
\text { regions receiving } \\
\text { Obj1 transfers }\end{array}$ & $\begin{array}{l}1989-1993, \\
1994-1999, \\
2000-2006\end{array}$ & $\begin{array}{c}\text { Up to } 3301 \\
\text { NUTS3 regions } \\
\text { (EU12/25) }\end{array}$ & $\begin{array}{l}\text { Panel: regression } \\
\text { discontinuity } \\
\text { analysis }\end{array}$ \\
\hline Dall'erba and Le Gallo (2008) & $\begin{array}{l}\text { Significant convergence takes place, but the funds have no } \\
\text { impact on it. }\end{array}$ & $\begin{array}{l}\text { SF payments and } \\
\text { remaining } \\
\text { commitments over } \\
1994-99 \text { (\% GDP) }\end{array}$ & 1989-1999 & $\begin{array}{l}145 \text { NUTS2 } \\
\text { regions (EU12) }\end{array}$ & $\begin{array}{l}\text { Cross-section: } \\
\text { Spatial lag model } \\
\text { with IV }\end{array}$ \\
\hline Esposti and Bussoletti (2008) & The impact of the Obj1 policy on growth is quite limited. & Obj 1 payments per & 1989-1999 & 206 NUTS2 & Panel: FD-GMM, \\
\hline
\end{tabular}




\begin{tabular}{|c|c|c|c|c|c|}
\hline & & capita (PPS) & & regions (EU15) & SYS-GMM \\
\hline Ramajo et al. (2008) & $\begin{array}{l}\text { Regions in the Cohesion-fund countries converge } \\
\text { separately from the rest of the European regions. }\end{array}$ & $\begin{array}{l}\text { Separate regressions } \\
\text { for regions } \\
\text { belonging to } \\
\text { Cohesion countries } \\
\text { vs. non-Cohesion } \\
\text { countries }\end{array}$ & $1981-1996$ & $\begin{array}{l}163 \text { NUTS2 } \\
\text { regions (EU12) }\end{array}$ & $\begin{array}{c}\text { Cross-section: } \\
\text { Robust OLS, } \\
\text { Spatial lag model }\end{array}$ \\
\hline Puigcerver-Peñalver (2007) & $\begin{array}{l}\text { SF have positively influenced the growth process of Obj1 } \\
\text { regions, although their impact has been stronger during } \\
1989-93 \text { than 1994-99. }\end{array}$ & $\begin{array}{c}\text { Total SF (\%GDP); } \\
\text { total SF; (SF of } \\
\text { region } i / \text { total SF } \\
\text { received by all } \\
\text { regions) }\end{array}$ & $\begin{array}{l}1989-1999, \\
1989-1993\end{array}$ & $\begin{array}{l}1 \text { NUTS2 } \\
\text { regions (EU10) }\end{array}$ & $\begin{array}{l}\text { Panel: Pooled OLS, } \\
\text { FE }\end{array}$ \\
\hline Rodriguez-Pose and Fratesi (2004) & $\begin{array}{l}\text { Limited impact of SF on growth; only investment in } \\
\text { education and human capital has medium-term positive } \\
\text { and significant returns. }\end{array}$ & $\begin{array}{l}\text { Obj1 commitments } \\
\text { (\% GDP) }\end{array}$ & 1989-1999 & $\begin{array}{l}152 \text { NUTS2 } \\
\text { regions (EU8) }\end{array}$ & $\begin{array}{l}\text { Cross-section and } \\
\text { panel: OLS, Pooled } \\
\text { GLS FE }\end{array}$ \\
\hline De Freitas et al. (2003) & $\begin{array}{l}\text { Obj1 regions do not show faster convergence than non- } \\
\text { Obj1 regions }\end{array}$ & $\begin{array}{l}\text { Dummy }=1 \text { for } \\
\text { regions receiving } \\
\text { Obj1 funding }\end{array}$ & 1990-2001 & $\begin{array}{l}196 \text { NUTS2 } \\
\text { regions (EU15) }\end{array}$ & Cross-section: OLS \\
\hline Cappelen et al. (2003) & $\begin{array}{l}\text { EU regional support has a significant and positive impact } \\
\text { on the growth performance of European regions. SF have } \\
\text { been more effective since the reform of 1989. The impacts } \\
\text { are stronger in more developed regions. }\end{array}$ & Obj1,2,5b (\% GDP) & $\begin{array}{l}1980-1997, \\
1980-1988, \\
1989-1997\end{array}$ & $\begin{array}{l}105 \text { NUTS1-2 } \\
\text { regions (EU9) }\end{array}$ & Cross-section: OLS \\
\hline
\end{tabular}


Table 2 Estimation of the growth equation for the subperiods (Structural Funds per capita)

\begin{tabular}{|c|c|c|c|c|c|c|c|c|c|c|c|c|c|c|c|c|c|c|}
\hline \multirow[b]{2}{*}{ Variables } & \multicolumn{6}{|c|}{ 1995-1999 } & \multicolumn{6}{|c|}{$2000-2006$} & \multicolumn{6}{|c|}{$2007-2009$} \\
\hline & (1) & (2) & (3) & (4) & (5) & $(6)$ & $(7)$ & $(8)$ & $(9)$ & $(10)$ & (11) & (12) & (13) & (14) & (15) & (16) & (17) & (18) \\
\hline $\ln \left(\mathrm{y}_{\mathrm{i}, t-1-1}\right)$ & $-0.2439 *$ & -0.2027 & $-0.2451^{*}$ & $-0.2838^{* *}$ & $-0.2599 *$ & $-0.2435 *$ & $-0.3812 * * *$ & $-0.4442^{* * *}$ & $-0.3829 * * *$ & $-0.3925 * * *$ & $-0.3803 * * *$ & $-0.3811 * * *$ & 0.0104 & -0.3100 & 0.0119 & 0.0053 & -0.0093 & -0.0177 \\
\hline & $(-1.680)$ & $(-1.438)$ & $(-1.678)$ & $(-1.990)$ & $(-1.800)$ & $(-1.693)$ & $(-3.823)$ & $(-5.075)$ & $(-4.030)$ & $(-3.995)$ & $(-3.973)$ & $(-3.815)$ & $(0.079)$ & $(-1.505)$ & $(0.092)$ & $(0.042)$ & $(-0.075)$ & $(-0.148)$ \\
\hline $\ln \left(\mathrm{s}_{\mathrm{i}, \mathrm{t}-1}\right)$ & 0.0054 & 0.0036 & 0.0060 & $0.0117^{*}$ & 0.0078 & 0.0053 & 0.0280 & $0.0300^{*}$ & $0.0316^{*}$ & 0.0296 & $0.0311^{*}$ & $0.0282^{*}$ & -0.0336 & -0.0340 & -0.0350 & -0.0311 & -0.0303 & -0.0338 \\
\hline & $(0.730)$ & $(0.476)$ & $(0.793)$ & $(1.739)$ & $(1.004)$ & $(0.760)$ & $(1.598)$ & $(1.689)$ & $(1.771)$ & $(1.599)$ & $(1.826)$ & $(1.674)$ & $(-1.020)$ & $(-1.062)$ & $(-0.904)$ & $(-0.914)$ & $(-0.989)$ & $(-1.051)$ \\
\hline $\ln \left(\right.$ gpop $\left._{\mathrm{i}, t-1}\right)$ & 0.0287 & 0.0331 & 0.0301 & 0.0376 & 0.0454 & 0.0319 & -0.0521 & -0.0577 & -0.0524 & -0.0612 & -0.0463 & -0.0518 & -0.0757 & $-0.1215^{* *}$ & -0.0784 & $-0.1106^{*}$ & -0.0983 & $-0.0908 * * *$ \\
\hline & $(0.699)$ & $(0.747)$ & $(0.770)$ & $(0.786)$ & $(1.289)$ & $(0.726)$ & $(-1.579)$ & $(-1.548)$ & $(-1.447)$ & $(-1.601)$ & $(-1.255)$ & $(-1.510)$ & $(-1.661)$ & $(-2.023)$ & $(-1.451)$ & $(-1.959)$ & $(-1.625)$ & $(-4.310)$ \\
\hline $\ln \left(\mathrm{sfpc}_{\mathrm{i}, \mathrm{t}-\mathrm{1}}\right)$ & $\begin{array}{c}0.0127^{* * * *} \\
(3.079)\end{array}$ & $\begin{array}{l}0.1571 \\
(1.431)\end{array}$ & $\begin{array}{c}0.0083 * * * \\
(2.863)\end{array}$ & $\begin{array}{l}-0.0383 \\
(-1.580)\end{array}$ & $\begin{array}{c}0.0180^{* * * *} \\
(4.996)\end{array}$ & $\begin{array}{l}0.0085 \\
(1.271)\end{array}$ & $\begin{array}{c}0.0034^{* * *} \\
(3.263)\end{array}$ & $\begin{array}{c}-0.1528 * * * \\
(-6.024)\end{array}$ & $\begin{array}{c}-0.0056^{* *} \\
(-2.530)\end{array}$ & $\begin{array}{c}-0.0435 * * * \\
(-3.713)\end{array}$ & $\begin{array}{c}0.0080 * * * \\
(4.168)\end{array}$ & $\begin{array}{l}0.0049 \\
(0.594)\end{array}$ & $\begin{array}{c}0.0531 * * * \\
(15.436)\end{array}$ & $\begin{array}{c}-0.7521 * * \\
(-2.143)\end{array}$ & $\begin{array}{c}0.0485 * * * \\
(3.037)\end{array}$ & $\begin{array}{c}-0.3539 * * * \\
\quad(-2.780)\end{array}$ & $\begin{array}{c}0.0761^{* * *} \\
(4.969)\end{array}$ & $\begin{array}{c}0.2058^{* * * *} \\
(4.418)\end{array}$ \\
\hline $\ln \left(\right.$ pat $\left._{\mathrm{i}, t-1}\right)$ & $\begin{array}{c}0.0134^{* * * *} \\
(3.923)\end{array}$ & $\begin{array}{c}0.0141^{* * * *} \\
(4.459)\end{array}$ & $\begin{array}{c}0.0079^{*} \\
(1.727)\end{array}$ & $\begin{array}{c}0.0113^{* * * *} \\
(3.036)\end{array}$ & $\begin{array}{c}0.0132^{* * *} \\
(3.453)\end{array}$ & $\begin{array}{c}0.0137^{* * * *} \\
(4.136)\end{array}$ & $\begin{array}{c}0.0067^{* *} \\
(2.314)\end{array}$ & $\begin{array}{c}0.0083^{* *} \\
(2.568)\end{array}$ & $\begin{array}{r}-0.0049 \\
(-0.806)\end{array}$ & $\begin{array}{c}0.0075^{* *} \\
(2.381)\end{array}$ & $\begin{array}{c}0.0082 * * * \\
(2.950)\end{array}$ & $\begin{array}{c}0.0069 * * * \\
(2.907)\end{array}$ & $\begin{array}{c}0.0098^{* * *} \\
(3.016)\end{array}$ & $\begin{array}{c}0.0095 * * * * \\
(3.748)\end{array}$ & $\begin{array}{l}0.0025 \\
(0.083)\end{array}$ & $\begin{array}{c}0.0098^{* * *} \\
(3.584)\end{array}$ & $\begin{array}{c}0.0094^{* * *} \\
(3.615)\end{array}$ & $\begin{array}{c}0.0090^{* * * *} \\
(3.351)\end{array}$ \\
\hline $\ln \left(\mathrm{hc}_{\mathrm{i}, t-1}\right)$ & $\begin{array}{l}0.0191 \\
(1.116)\end{array}$ & $\begin{array}{l}0.0205 \\
(1.196)\end{array}$ & $\begin{array}{l}0.0182 \\
(1.065)\end{array}$ & $\begin{array}{l}-0.0151 \\
(-0.590)\end{array}$ & $\begin{array}{l}0.0153 \\
(0.892)\end{array}$ & $\begin{array}{l}0.0191 \\
(1.114)\end{array}$ & $\begin{array}{c}0.0539 * * * \\
(5.490)\end{array}$ & $\begin{array}{c}0.0532^{* * * *} \\
(5.359)\end{array}$ & $\begin{array}{c}0.0541^{* * * *} \\
(5.473)\end{array}$ & $\begin{array}{l}-0.0058 \\
(-0.420)\end{array}$ & $\begin{array}{c}0.0531^{* * * *} \\
(5.260)\end{array}$ & $\begin{array}{c}0.0541^{* * *} \\
(5.990)\end{array}$ & $\begin{array}{c}-0.4697^{* * * *} \\
(-7.088)\end{array}$ & $\begin{array}{c}-0.4610^{* * * *} \\
(-8.398)\end{array}$ & $\begin{array}{c}-0.4727 * * * \\
(-6.177)\end{array}$ & $\begin{array}{c}*-0.9856 * * * \\
(-4.396)\end{array}$ & $\begin{array}{c}-0.4514^{* * * *} \\
(-7.932)\end{array}$ & $\begin{array}{c}*-4611 * * * \\
(-9.116)\end{array}$ \\
\hline $\ln \left(\mathrm{y}_{\mathrm{i}, \mathrm{t}-1}\right) * \ln \left(\mathrm{sfp} \mathrm{c}_{\mathrm{i}, \mathrm{t}-1}\right)$ & & $\begin{array}{l}-0.0145 \\
(-1.354)\end{array}$ & & & & & & $\begin{array}{c}0.0157^{* * *} \\
(6.061)\end{array}$ & & & & & & $\begin{array}{c}0.0797 * * * \\
(2.276)\end{array}$ & & & & \\
\hline $\ln \left(\right.$ pat $\left._{1, t-1}\right) * \ln \left(\mathrm{sfpc}_{\mathrm{i}, \mathrm{t}-1}\right)$ & & & $\begin{array}{c}0.0013^{* * * *} \\
(4.362)\end{array}$ & & & & & & $\begin{array}{c}0.0029 * * * \\
(3.515)\end{array}$ & & & & & & $\begin{array}{l}0.0012 \\
(0.243)\end{array}$ & & & \\
\hline $\ln \left(\mathrm{hc}_{\mathrm{i}, \mathrm{t}-\mathrm{l}}\right) * \ln \left(\mathrm{sfp} \mathrm{c}_{\mathrm{i}, \mathrm{t}-1}\right)$ & & & & $\begin{array}{c}0.0179 * \\
(1.841)\end{array}$ & & & & & & $\begin{array}{c}0.0154^{* * *} \\
(3.892)\end{array}$ & & & & & & $\begin{array}{c}0.1208^{* * *} \\
(3.119)\end{array}$ & & \\
\hline $\ln \left(\mathrm{sfp}_{\mathrm{i}, \mathrm{t}-\mathrm{l}}\right) *$ cohesion & & & & & $\begin{array}{c}-0.0169 * * * \\
(-4.994)\end{array}$ & & & & & & $\begin{array}{c}-0.0085 * * * \\
(-2.948)\end{array}$ & & & & & & $\begin{array}{c}-0.0509 * * \\
(-2.352)\end{array}$ & \\
\hline$\left[\ln \left(\mathrm{sfp}_{\mathrm{i}, \mathrm{t}-1}\right)\right]^{2}$ & & & & & & $\begin{array}{l}0.0008 \\
(0.722)\end{array}$ & & & & & & $\begin{array}{l}-0.0002 \\
(-0.193)\end{array}$ & & & & & & $\begin{array}{c}-0.0183 * * * \\
(-3.625)\end{array}$ \\
\hline Constant & $\begin{array}{l}2.3729 \\
(1.638)\end{array}$ & $\begin{array}{l}1.9708 \\
(1.426)\end{array}$ & $\begin{array}{l}2.4093 \\
(1.658)\end{array}$ & $\begin{array}{l}2.8817^{*} \\
(1.949)\end{array}$ & $\begin{array}{l}2.5912 * \\
(1.804)\end{array}$ & $\begin{array}{l}2.3807 \\
(1.643)\end{array}$ & $\begin{array}{c}3.4028^{* * *} \\
(3.553)\end{array}$ & $\begin{array}{c}4.0076^{* * *} \\
(4.772)\end{array}$ & $\begin{array}{c}3.4488^{* * * *} \\
(3.833)\end{array}$ & $\begin{array}{c}3.6658 * * * \\
(3.931)\end{array}$ & $\begin{array}{c}3.3954^{* * * *} \\
(3.686)\end{array}$ & $\begin{array}{c}3.3989 * * * \\
(3.520)\end{array}$ & $\begin{array}{l}1.0096 \\
(0.734)\end{array}$ & $\begin{array}{l}4.1089 * \\
(1.893)\end{array}$ & $\begin{array}{l}1.0286 \\
(0.737)\end{array}$ & $\begin{array}{l}2.7038^{*} \\
(1.849)\end{array}$ & $\begin{array}{l}1.0714 \\
(0.806)\end{array}$ & $\begin{array}{l}0.9263 \\
(0.744)\end{array}$ \\
\hline Number of regions & 348 & 348 & 348 & 348 & 348 & 348 & 626 & 626 & 626 & 626 & 626 & 626 & 273 & 273 & 273 & 273 & 273 & 273 \\
\hline Observations & 92 & 92 & 92 & 92 & 92 & 92 & 92 & 92 & 92 & 92 & 92 & 92 & 92 & 92 & 92 & 92 & 92 & 92 \\
\hline $\mathrm{R}^{2}$ within & 0.190 & 0.194 & 0.191 & 0.209 & 0.208 & 0.191 & 0.280 & 0.294 & 0.294 & 0.296 & 0.292 & 0.280 & 0.266 & 0.278 & 0.266 & 0.293 & 0.283 & 0.291 \\
\hline F test & 1.007 & 9.553 & 0.982 & 8.805 & 1.122 & 1.005 & 1123 & 157.6 & 141.7 & 251.7 & 267.3 & 185.2 & 28.23 & 2.386 & 20.99 & 9.756 & 1.614 & $2.36 \mathrm{E}+08$ \\
\hline $\mathrm{p}$-value $\mathrm{F}$ test & 0.426 & 0.000 & 0.450 & 0.000 & 0.357 & 0.433 & 0.000 & 0.000 & 0.000 & 0.000 & 0.000 & 0.000 & 0.000 & 0.028 & 0.000 & 0.000 & 0.141 & 0.000 \\
\hline
\end{tabular}

Coefficient significant at the 10 per cent $(*), 5$ per cent $(* *)$ or 1 per cent level $(* * *)$ 
Table 3 Estimation of the growth equation for the subperiods (Structural Funds as a \% of GDP)

\begin{tabular}{|c|c|c|c|c|c|c|c|c|c|c|c|c|c|c|c|c|c|c|}
\hline \multirow[b]{2}{*}{ Variables } & \multicolumn{6}{|c|}{$1995-1999$} & \multicolumn{6}{|c|}{$2000-2006$} & \multicolumn{6}{|c|}{$2007-2009$} \\
\hline & (1) & (2) & (3) & (4) & (5) & (6) & (7) & (8) & (9) & (10) & (11) & (12) & (13) & (14) & (15) & (16) & (17) & (18) \\
\hline $\ln \left(y_{i ; t-1-1}\right)$ & $\begin{array}{l}-0.2172 \\
(-1.445)\end{array}$ & $\begin{array}{l}-0.2308 \\
(-1.545)\end{array}$ & $\begin{array}{l}-0.2159 \\
(-1.435)\end{array}$ & $\begin{array}{l}-0.2231 \\
(-1.472)\end{array}$ & $\begin{array}{l}-0.2318 \\
(-1.606)\end{array}$ & $\begin{array}{l}-0.2197 \\
(-1.464)\end{array}$ & $\begin{array}{c}-0.3784 * * * \\
(-3.678)\end{array}$ & $\begin{array}{c}-0.4272 * * * \\
(-4.605)\end{array}$ & $\begin{array}{c}-0.3760 * * * \\
(-3.871)\end{array}$ & $\begin{array}{c}-0.3830 * * * \\
(-3.740)\end{array}$ & $\begin{array}{c}-0.3736 * * * \\
(-3.820)\end{array}$ & $\begin{array}{c}-0.3716^{* * * *} \\
(-3.770)\end{array}$ & $\begin{array}{l}0.0683 \\
(0.484)\end{array}$ & $\begin{array}{l}-0.0094 \\
(-0.064)\end{array}$ & $\begin{array}{l}0.0691 \\
(0.493)\end{array}$ & $\begin{array}{l}0.0674 \\
(0.492)\end{array}$ & $\begin{array}{l}0.0749 \\
(0.524)\end{array}$ & $\begin{array}{l}0.0711 \\
(0.512)\end{array}$ \\
\hline $\ln \left(\mathrm{s}_{\mathrm{i}, t-1}\right)$ & $\begin{array}{l}0.0020 \\
(0.278)\end{array}$ & $\begin{array}{l}0.0035 \\
(0.519)\end{array}$ & $\begin{array}{l}0.0030 \\
(0.417)\end{array}$ & $\begin{array}{l}0.0030 \\
(0.439)\end{array}$ & $\begin{array}{l}0.0060 \\
(0.926)\end{array}$ & $\begin{array}{l}0.0027 \\
(0.368)\end{array}$ & $\begin{array}{l}0.0277 \\
(1.611)\end{array}$ & $\begin{array}{l}0.0279 * \\
(1.717)\end{array}$ & $\begin{array}{l}0.0280 \\
(1.549)\end{array}$ & $\begin{array}{l}0.0272 \\
(1.539)\end{array}$ & $\begin{array}{l}0.0280^{*} \\
(1.693)\end{array}$ & $\begin{array}{l}0.0280 \\
(1.534)\end{array}$ & $\begin{array}{l}-0.0335 \\
(-0.993)\end{array}$ & $\begin{array}{l}-0.0410 \\
(-1.161)\end{array}$ & $\begin{array}{l}-0.0341 \\
(-0.977)\end{array}$ & $\begin{array}{l}-0.0313 \\
(-0.844)\end{array}$ & $\begin{array}{l}-0.0350 \\
(-1.007)\end{array}$ & $\begin{array}{l}-0.0450 \\
(-1.235)\end{array}$ \\
\hline $\ln \left(g p o p_{i, t-1}\right)$ & $\begin{array}{l}0.0252 \\
(0.685)\end{array}$ & $\begin{array}{l}0.0204 \\
(0.564)\end{array}$ & $\begin{array}{l}0.0239 \\
(0.692)\end{array}$ & $\begin{array}{l}0.0260 \\
(0.693)\end{array}$ & $\begin{array}{l}0.0425 \\
(1.225)\end{array}$ & $\begin{array}{l}0.0182 \\
(0.476)\end{array}$ & $\begin{array}{l}-0.0440 \\
(-1.171)\end{array}$ & $\begin{array}{l}-0.0616 \\
(-1.631)\end{array}$ & $\begin{array}{l}-0.0526 \\
(-1.391)\end{array}$ & $\begin{array}{l}-0.0498 \\
(-1.220)\end{array}$ & $\begin{array}{l}-0.0464 \\
(-1.232)\end{array}$ & $\begin{array}{l}-0.0628 * \\
(-1.905)\end{array}$ & $\begin{array}{l}-0.0113 \\
(-0.128)\end{array}$ & $\begin{array}{l}-0.0442 \\
(-0.537)\end{array}$ & $\begin{array}{l}-0.0118 \\
(-0.133)\end{array}$ & $\begin{array}{l}-0.0251 \\
(-0.321)\end{array}$ & $\begin{array}{l}-0.0528 \\
(-0.507)\end{array}$ & $\begin{array}{l}-0.0287 \\
(-0.461)\end{array}$ \\
\hline $\ln \left(\right.$ sfshare $\left._{\mathrm{i}, \mathrm{t}-1}\right)$ & $\begin{array}{c}0.0542 * * \\
(2.317)\end{array}$ & $\begin{array}{c}-0.6360^{* *} \\
(-2.533)\end{array}$ & $\begin{array}{c}0.0327 * * * \\
(2.858)\end{array}$ & $\begin{array}{l}-0.0128 \\
(-0.220)\end{array}$ & $\begin{array}{c}0.1327 * * * \\
(3.976)\end{array}$ & $\begin{array}{c}0.0970^{* * *} \\
(2.046)\end{array}$ & $\begin{array}{l}-0.0009 \\
(-0.152)\end{array}$ & $\begin{array}{c}-1.4356 * * * \\
(-9.361)\end{array}$ & $\begin{array}{c}-0.0364^{* * *} * \\
(-5.818)\end{array}$ & $\begin{array}{c}-0.1401^{* * *} \\
(-4.123)\end{array}$ & $\begin{array}{c}0.0490 * * * \\
(6.530)\end{array}$ & $\begin{array}{c}0.0572 * * * \\
(4.322)\end{array}$ & $\begin{array}{c}0.0813^{* * *} \\
(6.135)\end{array}$ & $\begin{array}{c}-3.1338 * * * \\
(-4.215)\end{array}$ & $\begin{array}{c}0.0789 * * * \\
(4.387)\end{array}$ & $\begin{array}{c}-1.1744 * * * \\
(-3.334)\end{array}$ & $\begin{array}{c}0.1997 * * * \\
(6.419)\end{array}$ & $\begin{array}{c}0.3053 * * * \\
(22.522)\end{array}$ \\
\hline $\ln \left(\right.$ pat $\left._{1, t-1-1}\right)$ & $\begin{array}{c}0.0154^{* * *} \\
(5.169)\end{array}$ & $\begin{array}{c}0.0147^{* * *} \\
(5.068)\end{array}$ & $\begin{array}{c}0.0102^{*} \\
(1.682)\end{array}$ & $\begin{array}{c}0.0149 * * * \\
(4.884)\end{array}$ & $\begin{array}{c}0.0135 * * * \\
(4.294)\end{array}$ & $\begin{array}{c}0.0152^{* * * *} \\
(4.919)\end{array}$ & $\begin{array}{c}0.0073 * * \\
(2.598)\end{array}$ & $\begin{array}{c}0.0080 * * \\
(2.507)\end{array}$ & $\begin{array}{l}-0.0011 \\
(-0.305)\end{array}$ & $\begin{array}{c}0.0083^{* *} \\
(2.600)\end{array}$ & $\begin{array}{c}0.0090^{* * * *} \\
(3.169)\end{array}$ & $\begin{array}{c}0.0081^{* * *} \\
(2.708)\end{array}$ & $\begin{array}{c}0.0118^{* * *} \\
(3.591)\end{array}$ & $\begin{array}{c}0.0097 * * * \\
(4.011)\end{array}$ & $\begin{array}{c}0.0106 * * \\
(2.093)\end{array}$ & $\begin{array}{c}0.0104^{* * * *} \\
(4.502)\end{array}$ & $\begin{array}{c}0.0106^{* * *} * \\
(4.257)\end{array}$ & $\begin{array}{c}0.0083 * * * \\
(5.449)\end{array}$ \\
\hline $\ln \left(\mathrm{hc}_{\mathrm{i}, t-1}\right)$ & $\begin{array}{l}0.0246^{*} \\
(1.672)\end{array}$ & $\begin{array}{l}0.0234 \\
(1.563)\end{array}$ & $\begin{array}{l}0.0238 \\
(1.577)\end{array}$ & $\begin{array}{l}0.0235 \\
(1.657)\end{array}$ & $\begin{array}{l}0.0210 \\
(1.388)\end{array}$ & $\begin{array}{l}0.0232 \\
(1.468)\end{array}$ & $\begin{array}{c}0.0610^{* * *} \\
(9.379)\end{array}$ & $\begin{array}{c}0.0630 * * * \\
(9.130)\end{array}$ & $\begin{array}{c}0.0631 * * * \\
(9.147)\end{array}$ & $\begin{array}{c}0.0435 * * * \\
(8.818)\end{array}$ & $\begin{array}{c}0.0622^{* * *} \\
(8.658)\end{array}$ & $\begin{array}{c}0.0623 * * * \\
(8.063)\end{array}$ & $\begin{array}{c}-0.4871^{* * * *} \\
(-6.682)\end{array}$ & $\begin{array}{c}-0.4739 * * * \\
(-6.965)\end{array}$ & $\begin{array}{c}-0.4883 * * * * \\
(-6.598)\end{array}$ & $\begin{array}{c}-0.6485^{* * * *} \\
(-5.295)\end{array}$ & $\begin{array}{c}-0.4716 * * * \\
(-6.789)\end{array}$ & $\begin{array}{c}-0.4538 * * * \\
(-6.775)\end{array}$ \\
\hline $\ln \left(\mathrm{y}_{\mathrm{i}, t-1}\right) * \ln \left(\mathrm{sfshare}_{\mathrm{i}, \mathrm{t}-\mathrm{l}}\right)$ & & $\begin{array}{c}0.0714^{* *} \\
(2.542)\end{array}$ & & & & & & $\begin{array}{c}0.1479 * * * \\
(9.231)\end{array}$ & & & & & & $\begin{array}{c}0.3266^{* * * *} \\
(4.380)\end{array}$ & & & & \\
\hline $\ln \left(\right.$ pat $\left._{1, t-1}\right) * \ln \left(\right.$ sfshare $\left._{\mathrm{i}, t-1}\right)$ & & & $\begin{array}{l}0.0098 \\
(1.541)\end{array}$ & & & & & & $\begin{array}{c}0.0168 * * * \\
(9.210)\end{array}$ & & & & & & $\begin{array}{l}0.0010 \\
(0.494)\end{array}$ & & & \\
\hline $\ln \left(\mathrm{hc}_{\mathrm{i}, \mathrm{t}-1}\right) * \ln \left(\mathrm{sfshare}_{\mathrm{i}, \mathrm{t}-1}\right)$ & & & & $\begin{array}{l}0.0235 \\
(0.909)\end{array}$ & & & & & & $\begin{array}{c}0.0480^{* * * *} \\
(3.414)\end{array}$ & & & & & & $\begin{array}{c}0.3904^{* * *} \\
(3.645)\end{array}$ & & \\
\hline $\ln \left(\right.$ sfshare $\left._{\mathrm{i}, t-1}\right) *$ cohesion $_{\mathrm{i}}$ & & & & & $\begin{array}{c}-0.1136^{* * *} \\
(-4.700)\end{array}$ & & & & & & $\begin{array}{c}-0.0620^{* * * *} \\
(-5.743)\end{array}$ & & & & & & $\begin{array}{c}-0.1692 * * * \\
(-3.662)\end{array}$ & \\
\hline$\left[\ln \left(\text { sfshare }_{i, t-1}\right)\right]^{2}$ & & & & & & $\begin{array}{l}-0.0363 \\
(-1.558)\end{array}$ & & & & & & $\begin{array}{c}-0.0435 * * * \\
(-4.051)\end{array}$ & & & & & & $\begin{array}{c}-0.1394^{* * *} \\
(-21.802)\end{array}$ \\
\hline Constant & $\begin{array}{l}2.1114 \\
(1.389)\end{array}$ & $\begin{array}{l}2.2335 \\
(1.472)\end{array}$ & $\begin{array}{l}2.1123 \\
(1.388)\end{array}$ & $\begin{array}{l}2.1757 \\
(1.410)\end{array}$ & $\begin{array}{l}2.3120 \\
(1.567)\end{array}$ & $\begin{array}{l}2.1138 \\
(1.386)\end{array}$ & $\begin{array}{c}3.3886^{* * * *} \\
(3.446)\end{array}$ & $\begin{array}{c}3.8152^{* * * *} \\
(4.224)\end{array}$ & $\begin{array}{c}3.3622 * * * \\
(3.643)\end{array}$ & $\begin{array}{c}3.4699 * * * \\
(3.554)\end{array}$ & $\begin{array}{c}3.3206 * * * \\
(3.505)\end{array}$ & $\begin{array}{c}3.2499 * * * \\
(3.397)\end{array}$ & $\begin{array}{l}0.8489 \\
(0.570)\end{array}$ & $\begin{array}{l}1.5309 \\
(0.987)\end{array}$ & $\begin{array}{l}0.8489 \\
(0.570)\end{array}$ & $\begin{array}{l}1.3626 \\
(0.962)\end{array}$ & $\begin{array}{l}0.6225 \\
(0.409)\end{array}$ & $\begin{array}{l}0.6756 \\
(0.474)\end{array}$ \\
\hline Number of regions & 348 & 348 & 348 & 348 & 348 & 348 & 626 & 626 & 626 & 626 & 626 & 626 & 273 & 273 & 273 & 273 & 273 & 273 \\
\hline Observations & 92 & 92 & 92 & 92 & 92 & 92 & 92 & 92 & 92 & 92 & 92 & 92 & 92 & 92 & 92 & 92 & 92 & 92 \\
\hline $\mathrm{R}^{2}$ within & 0.172 & 0.174 & 0.174 & 0.173 & 0.199 & 0.176 & 0.273 & 0.314 & 0.295 & 0.292 & 0.295 & 0.298 & 0.208 & 0.221 & 0.208 & 0.243 & 0.222 & 0.244 \\
\hline F test & 1.181 & 65.02 & 10.83 & 0.977 & 8.668 & 3.105 & 49.89 & 1077 & 85.01 & 64.56 & 50.88 & 95.76 & 0.119 & $5.430 \mathrm{e}+09$ & $1.120 \mathrm{e}+10$ & 5.606 & 0.188 & $6.420 \mathrm{e}+09$ \\
\hline$p$-value $F$ test & 0.323 & 0.000 & 0.000 & 0.453 & 0.000 & 0.006 & 0.000 & 0.000 & 0.000 & 0.000 & 0.000 & 0.000 & 0.994 & 0.000 & 0.000 & 0.000 & 0.897 & 0.000 \\
\hline
\end{tabular}

Coefficient significant at the 10 per cent $(*), 5$ per cent $(* *)$ or 1 per cent level $(* * *)$ 
